\title{
Üniversite Öğrencilerinin Vergi Algıları Üzerine Sosyal Medyanın Etkileri
}

\section{The Effect of Social Media on the Tax Perception of the Students}

\author{
Gülsüm Gürler Hazman ${ }^{1}$ \\ Gamze Akbay ${ }^{2}$
}

EMPIRICAL

ARTICLE

\begin{abstract}
ARTICLE INFO
Submitted : 09.09.2021

Revised : 23.11.2021

Accepted : 29.11.2021

Available : 25.12.2021

iThenticate similarity score: $8 \%$

JEL classification:

H2O, H26, H29

Keywords:

Social Media, Tax

Perception, Tax

Awareness

A B STRACT

Many studies in the literature explain the factors affecting taxpayers' taxpaying behaviors, including individual and environmental factors. Besides the mentioned factors, this study aims to evaluate the effect of social media on the tax perception of the taxpayers (students) with the more frequent use of social media in today's conditions. For this purpose, a conceptual framework was created by first scanning the literature on tax perception in the study. In order to create a framework that will help understand the reactions of taxpayers against tax applications, the study, in which students were preferred as a sample, was carried out among Afyon Kocatepe University, the faculty of Economics and Administrative Sciences' students between (01/06/2021)-(01/07/2021). It is aimed to determine how social media affects the tax perceptions of students in different departments, taking into account the tax perception of the students and their use of social media. In addition, as a general result; it has been determined that most of the students participating in the survey have a low level of interest in social media on tax-related issues.
\end{abstract}

Cite this article as: Gürler Hazman, G. \& Akbay, G. (2021). "Üniversite Öğrencilerinin Vergi Algıları Üzerine Sosyal Medyanın Etkileri", International Journal of Public Finance, 6(2), 312-331.

\footnotetext{
1 Prof. PhD., Afyon Kocatepe University, Department of Public Finance, Turkey, ORCID: 0000-0002-99534330, gulsumgurler@hotmail.com

2 PhD. Student, Afyon Kocatepe University, Department of Public Finance, Turkey, ORCID: 0000-00023969-0614,gmz_kby88@hotmail.com
} 


\begin{tabular}{|c|c|}
\hline MAKALE BíLGisi & Ö Z E T \\
\hline Gönderme: 09.09.2021 & \multirow{10}{*}{$\begin{array}{l}\text { Mükelleflerin vergi verme davranışlarını etkileyen faktörler, bireysel ve } \\
\text { çevresel faktörler olmak üzere literatürde pek çok çalışma ile } \\
\text { açıklanmaktadır. Bu çalışmada söz konusu faktörler yanında sosyal } \\
\text { medyanın günümüz koşullarında daha sık kullanılması ile birlikte, } \\
\text { mükelleflerin (öğrencilerin) vergi algısı üzerindeki etkisinin } \\
\text { değerlendirilmesi amaçlanmıştır. Bu amaçla çalışmada öncelikli olarak } \\
\text { vergi algısı hakkında literatür taranarak kavramsal çerçeve } \\
\text { oluşturulmuştur. Vergi uygulamaları karşısında mükelleflerin tepkilerinin } \\
\text { anlaşılmasında yardımcı olacak bir çerçeve oluşturmak için, örneklem } \\
\text { olarak öğrencilerin tercih edildiği çalışma, (01/06/2021)-(01/07/2021) } \\
\text { tarihleri arasında, Afyon Kocatepe Üniversitesi iiBF öğrencileri arasında } \\
\text { gerçekleştirilmiştir. Öğrencilerinin vergi algısı ve sosyal medya kullanımları } \\
\text { dikkate alınarak, farklı bölümlerdeki öğrencilerin vergi algılarını sosyal } \\
\text { medyanın nasıl etkilediğinin tespit edilmesi amaçlanmıştır. Ayrıca elde } \\
\text { edilen genel bir sonuç olarak; ankete katılan öğrencilerin çoğunluğunun } \\
\text { vergi ile ilgili konularda sosyal medya üzerinde ilgi düzeylerinin düşük } \\
\text { olduğu tespit edilmiştir. }\end{array}$} \\
\hline Düzeltme : 23.11.2021 & \\
\hline Kabul $\quad: 29.11 .2021$ & \\
\hline Yayın $\quad: 25.12 .2021$ & \\
\hline & \\
\hline JEL Kodu: & \\
\hline $\mathrm{H} 2 \mathrm{O}, \mathrm{H} 26, \mathrm{H} 29$ & \\
\hline Anahtar Kelimeler: & \\
\hline Sosyal Medya, Vergi & \\
\hline Algısı, Vergi Bilinci & \\
\hline
\end{tabular}

\section{Giriş}

Vergiler devletin önemli kamu gelir kaynağı olup, kamu harcamalarının finansmanı sağlama yanında mali olmayan amaçlarla da tahsil edilmektedir. Bu amaçlar özellikle iktisadi ve sosyal nitelikte olabilir. Vergi politikası ile devlet zaman zaman farklı amaçlar için vergi sistemini yeniden düzenlemektedir. Söz konusu düzenlemeler zaman içerisinde değişik amaçlara hizmet etmekle birlikte mükelleflerin tepki göstermesine sebep olabilmektedir. Vergiler mükellefin kişisel kullanılabilir gelirinde azalmaya neden olduğundan, mükelleflerin vergi algısı genellikle negatif olmakta yani mükellef vergiye karşı negatif tepkiler gösterebilmektedir. Bu durum vergi hasılatı açısından yani vergilemenin mali amacı açısından da ciddi sorunlara neden olmaktadır.

Vergi gelirlerini artırma yönelik ya da bunların tahsilatı yönünde alınan birtakım kararlar ve değişiklikler yapma, yasal düzenlemeler ile vergi yükünü değiştirme, mükelleflerin vergiye uyumunu etkilemektedir. Bu durum karşısında mükellefler arasında farklı etkiler oluşmakta ve vergiye karşı farklı mükellef tepkilerine yol açabilmektedir. Söz konusu tepkilerin doğru tahmin edilmesi için kanun koyucunun bireylerin vergilere yönelik oluşan algılarını ve bunların nedenlerini göz önünde bulundurması gerekmektedir. Çünkü vergiye karşı negatif algı artarsa, mükelleflerin vergiye gönüllü uyumu azalacak ve vergiden kaçınma ve kaçırma davranışları yaygınlaşacaktır.

Vergilere karşı oluşan tepkilerin birden çok nedeni olmakta ve kamu otoritesinin bu nedenleri dikkate alarak vergi politikasını şekillendirmesi gerekmektedir. Son dönemlerde teknolojik gelişmelerin hız kazanması da mükelleflerin vergi algısını etkilemekte hatta gösterecekleri tepkinin daha geniş kitlelere ulaşması ile vergiye karşı hızlı tepki gösterebilir hale gelinmektedir. Bu tepkiler sosyal medya aracılığı ile anlık verilebilmekte ve vergi politikalarından zaman zaman beklenen etkinin yavaşlaması 
hatta ortaya çıkmaması ya da tahmin edilen etkinin tersine gerçekleşmesi bile mümkün olabilmektedir. Dolayısıyla sosyal medyada gösterilen reaksiyonlar bir anda hem siyasi hem de sosyal hayatı etkileyebilir hale gelebilmektedir.

Buradan hareketle tasarlanan çalışma ile belli bir kitlenin (üniversite öğrencileri) vergi algıları ile sosyal medya kullanım alışkanlıkları arasında bir ilişki olup olmadığını ortaya koymak amaçlanmıştır. Burada sözü edilen hedef kitle üniversite öğrencileridir, bunun nedeni olarak sosyal medya kullanım sıklığının daha fazla olması ve ulaşılabilirlik kriteridir. Bu açıdan bahsedilen kitle araştırmanın ana kütlesini oluşturmaktadır. Böylece öğrencilerin vergi algılarının yüksek tutulmasında internet gibi iletişim araçlarının rolü tahmin edilecek ve internetin de vergi algısı ile olan bağlantısını tespit ederek, vergi algısını yükseltmede kamu spotları aracılığı ile halkın vergi algısını daha yüksek tutmak yönünde öneriler getirilebilecektir.

\section{Vergi Uyumu}

Kamu hizmetleri çeşitli nedenlerle günümüzde hızlı bir şekilde artarak büyük boyutlara ulaşmıştır. Gerek gelişmiş gerekse gelişmekte olan ülkelerde artan kamu harcamalarının finansmanı için vergiler önemli gelir kaynağı niteliğindedir. Ancak vergi gelirini sürekli olarak arttırmak her zaman mümkün olmamaktadır. Özellikle kayıt dışı ekonominin varlığı ve boyutları, vergi idaresinin etkinsizliği, vergi ahlakının zayıflığı gibi nedenlerle vergi gelirleri zaman zaman kamu harcamalarını karşılayamaz olabilir. Dolayısıyla bir toplumda vergi bilincini yüksek tutmak göz önünde bulundurulması gereken bir konu haline gelmektedir.

Özellikle kamu harcamalarının artmasıyla birlikte, bütçe açıklarını kapatmak adına bir taraftan sıkı maliye politikası tedbirleri ile kamu harcamalarında tasarruf ve performans konuları gündeme gelirken bir taraftan da vergi gelirlerindeki artışı sağlama üzerinde tedbirler alınmaktadır. Günümüzde vergi politikası şekillendirilirken vergi uyumunun sağlanması ve arttırılması yönünden çözüm önerileri üzerinde durulmaktadır.

Bilindiği üzere vergi, insanlık tarihi kadar eski bir konudur dolayısıyla verginin ne zaman, nerede ve nasıl ortaya çıktığı bilinmemektedir. Günümüz itibarıyle vergi hakkında bilinen gerçek ise tarihte en eski devletlerde bile var olmasıdır. Dolayısıyla ilk çağların büyük imparatorluklarının hepsinde çeşitli vergilerin bulunması bu durumu ortaya koymaktadır (Aksoy, 1998: 164). Vergi, tarihi ve sosyal bir olgu olup temelleri çok eskiye dayanan bir kamu geliridir. Tarihi süreç içerisinde ilk ve orta çağlarda devlete hediye olarak verilirken günümüzde ise zorunlu bir ekonomik değere dönüşmüş durumdadır (Orhaner, 2007: 144). Buradaki zorunluluktan kast edilen durum ise hukuki zorunluluktur. Bu tür kamu gelirlerinin toplanabilmesi için muhakkak bir kanunun olması, yasal bir dayanağının bulunması gerekmektedir (Aksoy, 1998: 142). Bu noktada vergilemede kanunilik ilkesi devreye girmektedir. Kanunilik ilkesi, vergi ve benzeri mali mükellefiyetlerin yasama organı aracılı̆ıyla kanunla konulması, değiştirilmesi ve kaldırılmasını ifade etmektedir (Edizdoğan vd. 2018: 263). 
Verginin ilk olarak anayasalarda yer alması İngiltere'de Magna Carta ile birlikte 1215 yılında başlamıştır (Akman, 2011: 22). Ülkemizde ise 1982 tarihli Türkiye Cumhuriyeti Anayasa'sının 73. Maddesinde "vergi ödevi" başlığı adı altında ele alınmıştır. Maddeye göre; "Herkes, kamu giderlerini karşılamak üzere, mali gücüne göre, vergi ödemekle yükümlüdür" (Anayasa md. 73/1). Bu bağlamda vergi, devletin vergileme yetkisine dayandırılmakta, ödeme gücü esas alınmaktadır (Edizdoğan, 1998: 44).

Genel özellikleri özetlenen vergiler görüldüğü üzere bireylerden karşılıksız ve cebren alınan parasal bir yükümlülük olup, kişisel kullanılabilir geliri büyük ölçüde etkilediğinden vergiye yönelik tutum ve davranışların söz konusu olması kaçınılmaz olmaktadır. Vergi mükelleflerinin gerekli tüm mükellefiyet sorumluluklarını zamanında yerine getirmesi ve bu durumu vergi mevzuatına uygun bir şekilde beyan etmesi, olarak ifade edilen vergi uyumunun gönüllüguünü sağlamak esastır (Roth et al. 1989: 21). Diğer bir ifade ile mükelleflerin vergi ile ilgili ödevlerini vatandaşlık görevi sayarak, bu ödevlerin yerine getirilme düzeyini ifade eden vergi uyumunun mükellefler tarafından gönüllü olarak sağlanması, vergi otoritesinin önemli bir görevi haline gelmiştir.

Vergi uyumsuzluğu ise mükelleflerin vergi kanunlarına aykırı bir şekilde hareket etmesi, vergi matrahının doğru bir tutarda gösterilmemesi, vergi beyannamelerinin zamanında verilmemesi ve kesinleşen vergilerin ödenmemesi şeklinde meydana gelmektedir (Roth et al. 1989: 2). Kısacası vergi uyumsuzluğu ile, vergi yükümlülüğü gereği ödenecek verginin olması gerekenden düşük ödenmesine neden olduğu ifade edilmektedir (Özperhiz, 2005: 90). Vergi uyumsuzluğunun gözlemlenen modellerini tanımlamak, açıklamak ve nihayetinde uyumsuzluğu azaltmanın yollarını bulmak dünya çapındaki tüm ülkeler için önemli bir konudur (Andreoni et al. 1998: 818). Bu kapsamda vergi mükellefi; vergi uyumsuzluğuna bağı olarak "vergi kaçırma, vergiden kaçınma, vergi borcunun geciktirilmesi ve verginin yansıtılması" davranışlarını sergileyebilmektedir. İşte burada vergi uyumu ile amaçlanan husus, vergi gelirlerini azaltıcı tüm bu davranışların önlenebilmesidir (Aktan \& Çoban, 2007: 3).

\section{Vergi Uyumunu Açıklamada Davranışsal İktisat ve Vergi Uyumunu Etkileyen Faktörler}

Literatürde, vergi uyumunu açıklamada kullanılan temelde iki teori bulunmaktadır. Bunlardan ilki Rasyonel Beklentiler Teorisi (Allingham \& Sandmo Modeli) adıyla bilinen Klasik yaklaşımdır. Bu çalışmada vergilerin verimli bir şekilde tahsisini teşvik etmek için yapılması gerekenler vurgulanmaktadır. Ayrıca vergi kayıp ve kaçaklarının ortaya çıktığı durumda bunların nasıl azaltılacağı araştırılmakta ve kaçakçııı eğilimine karşı koymak amacıyla hükümetin kullanabileceği politika araçlarının başında vergi oranlarının geldiği açıklanmaktadır. (Allingham \& Sandmo, 1972: 338). Diğeri ise Ahlaki Duygular Teorisi ya da Tutumsal Model olarak bilinen Sosyal-Psikolojik yaklaşımdır (Kitapcı, 2015: 40). Allingham \& Sandmo (1972) teorisinde insanın "ekonomik insan" güdüsüyle hareket ederek özü gereği faydasını maksimize 
etmeyi tercih edecektir. Dolayısıyla bu tutumu, vergi ödeme/ödememe davranışını da etkileyecektir. Geliştirdikleri teoriye göre vergi mükellefleri vergi oranı, ceza miktarı ve denetim sıklığı gibi unsurları doğru tahmin ederek, hareket etmektedir örneğin ceza miktarı ve denetim oranındaki artış, vergi gelirini olumlu etkilemekte yani beyan edilen verginin artmasına yol açmaktadır.

Vergi uyumunu açıklayan diğer bir yaklaşım olan "Ahlaki Duygular Teorisi” ya da "Tutumsal Model" adıyla bilinen Sosyal - Psikolojik yaklaşımda ise vergi uyumu modellerinde etik ve sosyal dinamiklerin genellikle inmal edildiği dile getirilmektedir (Kitapcı, 2015: 47). Bu nedenle vergi mükelleflerinin yüksek bir vergi uyumu gösterebilmesi açısından ekonomik, psikolojik ve sosyolojik yaklaşımların birlikte ele alınarak multi-disipliner bir yöntemin uygulanması gerektiğini ifade etmektedir (Torgler, 2007: 64). Sosyal-Psikolojik yaklaşımın temel sorusu "Niçin çoğu insan denetim ihtimali ve vergi cezaları çok düşük olmasına rağmen vergilerini ödeme eğilimindedirler?" sorusudur (Lubian \& Zarri, 2011: 2). Çünkü uzun yıllar boyunca vergi uyumu literatüründe "insanların neden vergi ödediği" sorusundan ziyade "insanların neden vergi kaçırdığı" sorusu üzerinde durulmakta ve vergi uyumsuzluğuna dair çözümler bulunmaya çalışılmaktadır (Kitapcı, 2015: 48).

Ahlaki duygular teorisi, mükelleflerin vergi ödeme/ödememe tercihlerini belirleyen tek etkenin ekonomik çıkar veya bireysel fayda olmadığını onların psikolojik algılamalarının, etik duyarlılılarının ve çeşitli bilişsel süreçlerin belirlediğini savunmaktadır (Sirkeci \& Elbeyoğlu, 2019: 11). Bu teori ile birlikte birinci nesil davranışsal iktisat başlamış kabul edilmektedir. Ikinci nesil davranışsal iktisat olarak adlandırılan dönem ise Tversky ve Kahneman ile başlamıştır. Kahneman'ın, 1979 yılında Econometrica dergisinde Tversky ile ortak yayımlanan makalesinde risk altında karar vermenin tanımlayıcı bir modeli olarak beklenen fayda teorisinin bir eleştirisini sunmakta ve beklenti teorisi adı verilen alternatif bir model geliştirmektedir (Kahneman \& Tversky, 1979: 263). Sonraki yıllarda davranışsal iktisat hakkında araştırmalar sürmüş ve son dönemde davranışsal iktisada katkılarından dolayı Richard H. Thaler'a 2017 yılında Nobel iktisat Ödülü verilmiştir. Thaler, iktisadi ajanların karar alma sürecini etkileyen "Dürtme (Nudge)" yaklaşımında, insanların rasyonel oldukları varsayımının sürekli geçerli olmayacağını, bazı sosyal tercihlerin hatta bazı insan özelliklerinin davranışlara etkisini vurgulamaktadır.

Davranışsal iktisat içinde yer alan "dürtme" veya "seçim mimarisi", bir tür uyaran mekanizması işlevindedir. Seçim mimarisinin doğru kurgulanması önemlidir çünkü seçim mimarisi yani kişinin kazanılması istenen alışkanlığın dürtüsünü doğru kurgulanması gereklidir. Dürtü, olması gereken davranışı otomatik davranış haline dönüştürmektedir (Akın, 2019: 159). Dolayısıyla kişi bu davranışı yapmadığı zaman rahatsızlık hissetmekte, bu rahatsızlık hissi kişiyi söz konusu ulaşılmak istenen davranışa yöneltmektedir. Bu konu vergi uyumu açısından incelendiğinde ise, vergi uyumunu arttıracak dürtülerin doğru belirlenmesi önem arz etmektedir. Vergi ödemenin bir vatandaşlık görevi olduğu başta olmak üzere mükellef üzerinde vergi uyumu algısını pozitif etkileyecek kamu spotları, bilgilendirme, verginin önemi hakkında bültenler, konferanslar gibi dürtüler arttırılmalıdır. Çalışmada öğrenci kitlesi 
örneklem olarak ele alındığından, öğrencilerin vergi algısını arttırmada sosyal medya etkisi sorgulanmaktadır. Dolayısıyla çalışmada sosyal medya aracılığı ile çeşitli dürtü mekanizmaları kullanılabilir böylece gönüllü vergi uyumu arttırılabilir.

2017 yılında ise Sunstein ve Thaler geliştirdikleri liberteryan paternalizm kavramıyla davranışsal iktisada katkıda bulunmuşlar ve bu anlayışa göre bireylerin herhangi bir baskı ve zorlama olmadan istedikleri tercihleri yapma konusunda seçim özgürlüğüne sahip olduklarının altı çizilmiştir. Burada sadece toplumdaki bireylerin baskı olmadan seçme özgürlüklerine dayanarak karar alma süreçlerinde birtakım yönlendirmeler ile istenilen yani hedeflenen davranış modellerine ulaşmak arzulanmaktadır (Thaler \& Sunstein, 2019, 1-3). İkinci nesil davranışsal iktisadın alt başlıkları sayılabilecek bu hususların, toplumda vergi algısının pozitif yönlü oluşmasında etkisi söz konusudur. Bu açıdan kamu otoritesinin vergileme karşısında olumlu davranış modellerini arttıracak mekanizmalara odaklanarak, vergi potansiyelini yakalaması zaruri bir hedef olmalıdır.

Vergi uyumunu açıklayan teoriler yanında vergi uyumunu nelerin etkilediği de literatürde üzerinde fazlaca durulan konular arasındadır. Özellikle devletin finansman kaynakları içerisinde en önemli yeri teşkil eden vergi gelirlerini arttırmak hususunda yeni vergi yöntem ve arayışları arttırılmalıdır. 21. yüzyılda devletin hem yönetim hem de hizmet anlayışında ortaya çıkan değişim ve gelişmeler sonucunda devletin üstlenmiş olduğu görevleri artmakta ve bu görevleri yerine getirebilmesi adına daha fazla finansmana ihtiyaç duymaktadır. Bu arayış kapsamında gelir, servet ve harcamalar üzerinden alınan vergilerin oranları arttırılmaya çalışılmakta ve yeni vergiler konularak vergi mükelleflerinin kişisel kullanılabilir gelirleri bu uygulamalardan etkilenmektedir (Aydın, 2013: 3). Bu noktada mükellefler ya vergiyi gönüllü bir şekilde ödemeye veya ödememeye yönelmektedir ki; bu davranışları açıklayan birçok faktör söz konusudur. $\mathrm{Bu}$ faktörler temelde dört ana kategoride sınıflandırılmaktadır. Bunlar; ekonomik, sosyal ve demografik, ahlaki, psikolojik, siyasi ve yönetimsel faktörler şeklindedir (Aktan \& Çoban, 2006: 137). Bu faktörler içinde yer alan ekonomik faktörler içerisinde; serbest piyasa koşulları, ekonomideki istikrar durumu, GSMH (Gayrisafi Milli Hasıla), kayıt dışı ekonomi, mükellefin ödeme gücü gibi alt başlıklar mevcuttur. Piyasadaki fiyat istikrarının /istikrarsızlığının ve ekonomik büyümenin vergi algısı üzerindeki etkisini araştıran pek çok araştırma yapılmış olup, ekonomik büyüme ile gönüllü vergi uyumunun büyük ölçüde pozitif ve anlamlı ilişkide oldukları gözlenmiştir. Demografik ve sosyal faktörler olarak ise; aile ölçeği, eğitim düzeyi, yaş, cinsiyet, medeni hal, meslek ve sosyal çevre gibi unsurlar dikkat çekmektedir. Dini inanç ile geleneklere bağlılık ise vergi uyumunu etkileyen ahlaki faktörler arasında yer almakta ve inancı gereği vergi kaçırmanın yanlış olduğuna inanan bir mükellefin vergiye gönüllü uyumunun daha fazla olduğu ifade edilmektedir.

Mükelleflerin vergi ile ilgili sorumluluklarını tam ve zamanında yerine getirme hususunda gösterdikleri hassasiyeti ifade eden vergi bilinci, vergilemede gönüllü uyum için önem arz eden bir psikolojik faktördür. Vergi ödemenin bir vatandaşlık görevi olduğuna inanmak da psikolojik faktörler arasında yer almaktadır. Vergi uyumu sadece mükellef kaynaklı sebeplerden etkilenmez, mükellef dışında siyasi ve yönetimsel 
faktörler de söz konusudur. Özellikle devlete duyulan güven ve iktidar ile uyum gibi faktörlerin de mükellefin vergi algısı üzerinde belirleyici role sahip olduğu yapılan ampirik çalışmalar ile de desteklenmektedir. Daha çok vergi sistemi ve vergi tekniği olarak özetlenebilen yönetimsel faktörler ise; vergi oranları, vergi denetimlerinin sıklı̆̆ı, vergi cezalarının caydırıcılığı, mali aflar, istisna ve muafiyetler, vergi mevzuatının karmaşıklığı, vergi daire ile mükellef ilişkilerinin etkisi gibi hususlardan oluşmaktadır.

Çalışmanın konusunu oluşturan "sosyal medya ve vergi uyumu ilişkisi" açısından sosyal medyanın bir çeşit sosyal ortam ya da sosyal çevre olması nedeniyle vergi uyumunu etkileyen "sosyal faktörler" içerisinde sayılabileceği düşünülmektedir. Çünkü teknolojinin ve içinde bulunulan çağın getirdiği yenilikler içerisinde internet kullanımın yaygınlaşması, bilinen bir gerçektir ve bu süreçte sosyal medya olarak ifade ettiğimiz çeşitli paylaşım ağları mevcuttur. Dolayısıyla bu çalışma ile sosyal faktörler içerisinde sayabileceğimiz sosyal medyanın vergi uyumuna etkisi sorgulanmak istenmiştir.

Şu da bir gerçektir ki; vergiye karşı gösterilen en olumlu tutum; vergi mükelleflerinin vergiye gönüllü uyum sağlamalarıdır. Bu doğrultuda, vergi kapsamında mükelleflerin seçimlerini hangi şartlarda belirlediğini anlamak önem arz etmektedir (Norris, 1999: 264).

\section{Vergi Uyumu ve Sosyal Medya İlişkisi}

Sosyal medya, günümüz dünyasında internet teknolojisinin de gelişmesiyle etkin şekilde kullanılan bir iletişim aracı görünümündedir. Sosyal medya, "çeşitli mecralarda kullanıcıların bilgi, duygu, düşünce, tecrübe, ilgi ve başka diğer verileri sesli ve görüntülü olarak tanıdığı ya da tanımadığı kişilerle paylaşmasıdır”, şeklinde genel olarak tanımlanabilir (İnce \& Koçak, 2017: 738). Bir başka tanım olarak Henderson ve Bowley sosyal medyayı; bir kullanıc topluluğu arasında katılım, bağlantı, kullanıcı tarafından oluşturulan içerik, bilgi paylaşımı, işbirlikçi çevrimiçi uygulamalar ve teknolojiler şeklinde ifade etmektedir (Henderson \& Bowley, 2010: 239). Sosyal medya, günümüzde kullanılan önemli iletişim kanallarından bir tanesidir. Sosyal medya üzerinden insanlar hem birbirleriyle iletişim kurabilmekte hem de birçok veri ve bilgiyi aralarında paylaşabilmektedir. Bu bağlamda sosyal medya sayesinde insanlar seyirci statüsünden kullanıcı statüsüne geçerek kendi içeriklerini oluşturmakta ve bu içeriklerini diğer insanlarla paylaşarak duruma müdahil olmaktadır (İnce \& Koçak, 2017: 738).

Sosyal medya sadece insanlar arası iletişimde değil kamu kurumları tarafından da vatandaşlara kaliteli hizmet verme noktasında günümüzde yoğun bir şekilde kullanılmaktadır (Doğan, 2015: 24). Söz konusu gelişim ile birlikte internet ve sunduğu imkanları kuruma entegre eden kamu kurumlarından biri de Gelir İdaresi Başkanlığı'dır. Başkanlık vergi ile ilgili hatırlatma ve duyuruların yapılması, vergi ile ilgili değişikliklerin paylaşılmasında sosyal medya araçlarını yoğun ve etkin bir şekilde kullanmaktadır. Buradan hareketle söz konusu paylaşımların hem bilgiye hızlı ulaşımı sağlama hem de vergiye gönüllü uyumu arttırma etkisi dikkat çekmektedir. 
Mükellefler, vergi ile ilgili gelişmelerden haberdar olmak, ödev ve haklarını öğrenerek bu mecradaki araçlarla konunun tarafları ile etkileşim içerisinde bulunmak isteyecektir (Çanakkale, 2016: 61). Bu bağlamda Gelir İdaresi Başkanlığı 2020 yılı faaliyet raporlarına göre kullanıcıların intiyaçları doğrultusunda içerik ve video sayısını arttırılmıştır. Ayrıca aktif olarak yer alınan platform sayısı artırılarak daha fazla kitleye ulaşılma amaçlanmıştır. Yapılan çalışmalar sonucunda sosyal medya platformlarındaki takipçi sayısında artış gözlemlenmiştir (GiB Faaliyet Raporu, 2020). Gelir İdaresi Başkanlığı'nın sosyal medya platformlarını kullanan takipçi sayıları ve yıllar içindeki değişimi aşağıdaki şekilde verilmiştir.

Şekil 1: Gelir İdaresi Başkanlığı Yıllara Göre Facebook Takipçi Sayısı

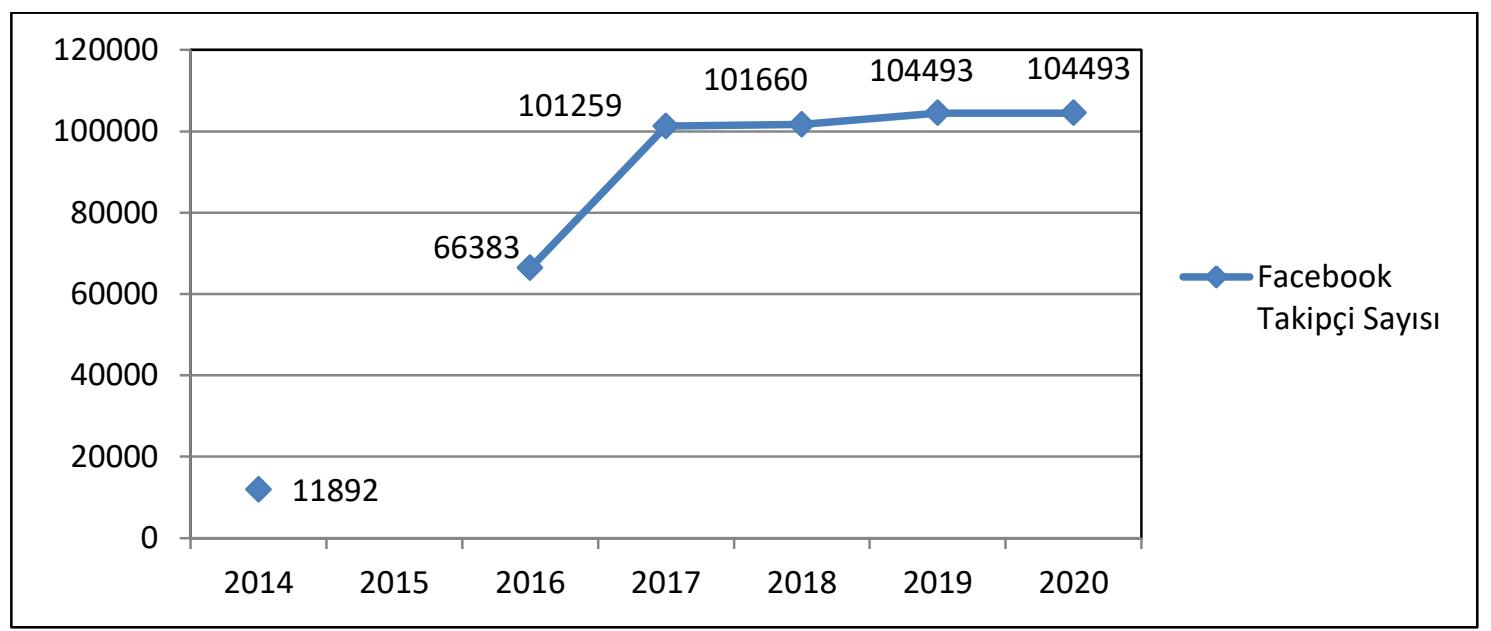

Kaynak: (GiB 2014-2020 Faaliyet raporları verileri doğrultusunda yazarlar tarafından oluşturulmuştur. 2015 yılı verisi mevcut değildir.)

Şekil 1'den de görüldüğü üzere 2014-2020 yılları verileri doğrultusunda özellikle 2016 yılından 2017 yılına geçişte Gelir Idaresi Başkanlığı Facebook sosyal medya platformu takipçi sayısında ciddi artış olduğu gözlemlenmektedir.

Şekil 2: Gelir İdaresi Başkanlığı Yıllara Göre Instagram Takipçi Sayısı

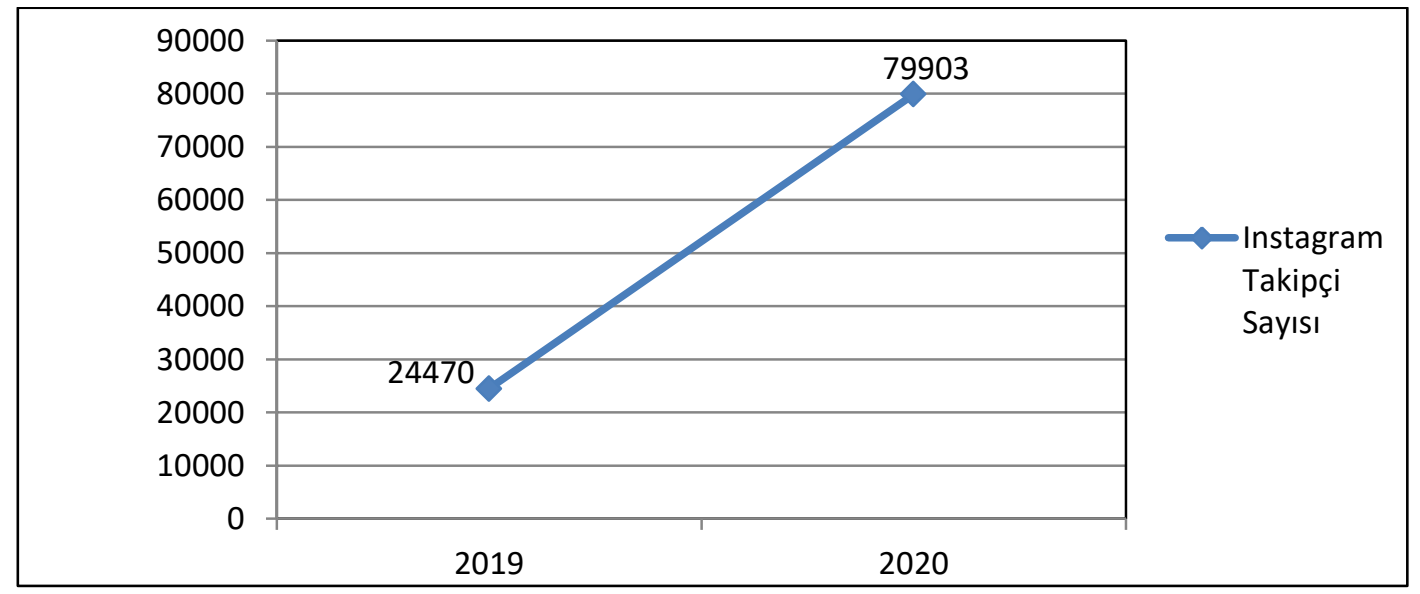

Kaynak: (GIB 2019-2020 Faaliyet raporları verileri doğrultusunda yazarlar tarafından oluşturulmuştur.) 
Şekil 2'ye göre ise 2019-2020 yılları verileri doğrultusunda Gelir İdaresi Başkanlığı Instagram sosyal medya platformu takipçi sayısında hızlı bir artış olduğu gözlemlenmektedir. Şekil 1 ve şekil 2 göstermektedir ki, son yıllarda sosyal medya takipçi sayıları artış göstermiştir. Özellikle covid 19 ile birlikte 2019 yılından 2020 ye geçiş ile birlikte bu kullanım daha da artmıştır.

Yapılan çeşitli araştırmalar göstermektedir ki; gençler internette geçirdikleri zamanın büyük çoğunluğunu sosyal medya kullanımına ayırmaktadır (Obee, 2012: 8). Dolayısıyla özellikle genç nüfusun bu kadar zamanını alan sosyal medyanın, kullanıcıların vergi algılarının değişip değişmediği yani sosyal medyanın vergi algısı üzerindeki etkisi araştırılmak istenmiş ve bu amaç çalışmanın temel hedefini oluşturmaktadır. Bu amaç doğrultusunda odak grup olarak üniversite öğrencileri belirlenmiş ve sosyal medyanın üniversite öğrencilerinin vergi algıları üzerindeki etkileri üzerinde durulmuştur. Bunun için Afyon Kocatepe Üniversitesi İdari ve İktisadi Bilimler Fakültesi öğrencilerine anket çalışması uygulanmıştır. Elde edilen verilerin analizi sosyal bilimlerde sıklıkla kullanılan istatistik programlarından olan SPSS' den yararlanılarak gerçekleştirilmiştir.

\section{Araştırmanın Metodolojisi}

Araştırmanın amacı; üniversite öğrencilerinin vergi algıları üzerinde sosyal medya kullanım alışkanlıkları bir etkisi olup olmadığını ortaya koymaktır. Böylece öğrencilerin vergi algılarının yüksek tutulmasında internet gibi iletişim araçlarının rolü tahmin edilecek ve internetin de vergi algısı ile olan bağlantısını tespit ederek, vergi algısını yükseltmede kamu spotları aracılığı ile halkın vergi algısını daha yüksek tutmak yönünde öneriler getirilebilecektir. Anket formu geliştirilirken bu konuda yapılmış ulusal ölçekte bir çalışma olmadığından yani hazırda bir anket formu olmadığından, konu ile ilgili tüm uluslararası ve ulusal çalışmalar irdelenerek anket formu tasarlanmıştır.

Anket, (01/06/2021)-(01/07/2021) tarihleri arasında, Afyon Kocatepe Üniversitesi IïBF öğrencilerinin not bildirim sistemi olan OBiS aracılı̆̆ı ile gerçekleştirilmiştir. Tasarlanan ankette ilk altı soru kişisel bilgilerle ilgilidir. Daha sonraki sorular ise öğrencilerin sosyal medya kullanım düzeyleri ve sosyal medyada vergi ile ilgili konulara duydukları özen ve ilgi ile ilgilidir. Ankette 'Likert ölçeği' geliştiricisi olan Rennis Likert'in adıyla anılan ve sosyal bilimler alanında yaygın olarak kullanılan ölçek tercih edilmiştir. Bu ölçekte deneğe çeşitli ifadeler ve yargılar yöneltilir. Denekten, bu yargılara veya ifadelere katılıp katılmama derecesini belirtmesi istenir. Kategori sayısı olarak 5,7,9 ve 11'li olabilen bu ölçek, yaygın olarak 5'li Likert ölçeği tercih edilmektedir (Altunışık vd., 2010: 115). Anket formunda değişkenleri ifade eden sorularda likert tipi ölçekten yararlanılmıştır.

Çalışmada hangi analizin yapılacağına karar vermek adına önce normallik testi yapılmıştır. Kolmogorov Simirnov testi sonucuna göre çalışmada verilerin normal dağılmadığı belirlenmiştir. Demografik testler ve çapraz tablolar ile yapılan değerlendirmeler sonrasında, veriler normal dağılmadığı için birbirinden bağımsız iki 
veya daha fazla örneklemin bağımlı bir değişkene ait ölçümlerinin karşılaştırılmasında kullanılan Kruskall-Wallis, bu çalışma için uygun görülmüştür. Çünkü çalışmada iỉBF öğrencilerinin bölümleri dikkate alınarak 5 grup üzerinden araştırma yapılmıştır:

1. Grup: İşletme bölümünde olanlar,

2. Grup: Iktisat bölümünde olanlar,

3. Grup: Maliye bölümünde olanlar,

4. Grup: Siyaset Bilimi ve Kamu Yönetimi bölümünde olanlar,

5. Grup: UTF bölümünde olanlar,

Kruskall-Wallis testi parametrik olmayan veriye sahip birbirinden bağımsız iki veya daha fazla örneklemin bağımlı bir değişkene ait ölçümlerinin karşılaştırılmasında kullanılır. Çalışmada bu analizle araştırılmak istenen başıı;

iiBF öğrencileri (bölüm bazında) arasında sosyal medya ve vergi algısı hakkında anlamlı bir farklılık söz konusu olup olmadığı, şeklindedir.

\subsection{Araştırmanın Evreni ve Örneklem}

Çalışmada Afyon Kocatepe Üniversitesi İktisadi ve İdari Bilimler Fakültesi aktif olarak kayıtlı 2021 Ağustos itibarıyle 2694 öğrenci ana kütle olarak belirlenmiştir. Örneklem grubu olarak ise on-line olarak ankete katılım gösteren 219 öğrenci ulaşılabilirlik kriteri dikkate alınarak ankete katılımcı olmuştur. Elde edilen bulgular, SPSS 18 programında analiz edilmiştir.

\subsection{Veri Toplama Aracı}

Yapılan çalışma ile üniversite öğrencilerinin sosyal medya kullanımının vergi algısına etkisini tahmin etmeye çalışıımıştır. Hazırlanan ankette toplam 21 sorudan oluşan değişkenler mevcuttur.

Yapılan güvenilirlik testinin sonucuna göre Cronbach's Alpha değeri $(\alpha) 0,783$ olarak hesaplanmıştır (Özdamar, 2002: 673). Bu oran yüksek bir değerdir, bu durumda testin güvenilirliğinin yüksek olduğu söylenebilir. Yapılan normallik testi sonucunda (Kolmogorov-Smirnow) ${ }^{3}$ significant değeri (f değeri) 0,00 olarak hesaplanmıştır. $\alpha<$ 0,05 olduğu için, veriler normal dağılım sergilememektedir. Uygun analiz tekniğinin seçilebilmesi için normal dağılım testinin yanı sıra varyansların homojenliği testi yapılmıştır. Bu test sonucunda bazı değişkenler için $\alpha>0,05$ iken bazı değişkenler için ise $\alpha<0,05$ olduğundan homojenlik tüm değişkenler için mevcut değildir veriler de normal dağılmadığından parametrik olmayan testlerin tercih edilmesi uygun olacaktır.

\footnotetext{
${ }^{3}$ SPSS' te normal dağılıma uygunluk testi ( gruplandırılmamış veriler için) parametrik olmayan testlerden tek örneklem Kolmogorov- Smirnow testi ile yapılır.
} 


\section{Verilerin Analizi}

Gerçekleştirilen çalışmada amaç, üniversite öğrencilerinin sosyal medya kullanım durumları ile vergi algıları arasındaki ilişkiyi tespit etmektir. Bu amaç için geliştirilen hipotez testlerine geçmeden önce öğrencilerin demografik özelliklerinin gösterildiği dağılıma bakmak gereklidir.

Tablo 1: Katılımcılar Hakkında Demografik Analizler

\begin{tabular}{|c|c|c|c|c|c|}
\hline & SIKLIK & $\%$ & & SIKLIK & $\%$ \\
\hline 1) CINSIYET & & & 4) AiLENIN AYLIK GELIRi & & \\
\hline Kadın & 90 & 41,1 & $3000 \mathrm{TL}$ ve altı & 92 & 42,0 \\
\hline Erkek & 129 & 58,9 & 3001 TL- 6000 TL & 103 & 47,0 \\
\hline 2) YAŞ & & & $6001 \mathrm{TL}-10.000 \mathrm{TL}$ & 22 & 10,0 \\
\hline $18-20$ & 57 & 26,0 & 10.001 TL ve üzeri & 2 & 0,9 \\
\hline $21-24$ & 141 & 64,4 & $\begin{array}{l}\text { 5) SOSYAL MEDYA HESABINIZ } \\
\text { VAR MI }\end{array}$ & & \\
\hline 25 ve üzeri & 21 & 9,6 & Evet & 208 & 95,0 \\
\hline 3) вÖLÜM & & & Hayır & 11 & 5,0 \\
\hline İktisat & 23 & 10,5 & 6) SOSYAL MEDYA HESAP SAYISI & & \\
\hline İşletme & 28 & 12,8 & 1 adet & 85 & 38,8 \\
\hline Maliye & 109 & 49,8 & 2 adet & 53 & 24,2 \\
\hline $\begin{array}{l}\text { Siyaset Bilimi ve } \\
\text { Kamu Yönetimi }\end{array}$ & 28 & 12,8 & 3 adet & 47 & 21,5 \\
\hline $\begin{array}{l}\text { U. Ticaret ve } \\
\text { Finansman }\end{array}$ & 31 & 14,2 & 4 adet ve fazlası & 34 & 15,5 \\
\hline
\end{tabular}

Tablo 1'de görüldüğü üzere, öğrencilerin \% 58.9'unu erkek öğrenciler, \% 41.1'ini ise bayan öğrenciler oluşturmakta ve \%26'sı 18 ile 20 yaş arasında, \% 64.4'ü yani çoğunluğu 21 ile 24 yaş aralığındadır. Öğrencilerin bölüm dağılımlarına bakıldığında ise; çoğunluğu yani \% 49.8'i maliye bölümde eğitim görmektedir. Öğrencilerin ailelerinin gelir düzeyleri ise $3000 \mathrm{TL}$ ile $6000 \mathrm{TL}$ arasında yoğunlaşmaktadır. Katılımcıların \%95'inin sosyal medya hesapları olduğu ve 219 öğrencinin 85 tanesinde sadece 1 adet sosyal medya hesabı olduğu görülmektedir.

Araştırma bulguları için öncelikle katılımcı olan öğrencilerin "sosyal medya kullanım hakkındaki" sorulara verdikleri cevapları cinsiyet değişkenini dikkate alarak görebiliriz. Bunun için çapraz tablolar kullanılmıştır. 
Gürler Hazman, G. \& Akbay, G. (2021). "Üniversite Öğrencilerinin Vergi Algıları Üzerine Sosyal Medyanın Etkileri", International Journal of Public Finance, 6(2), 312-331.

Tablo 2: Sosyal Medya Kullanımı ile Cinsiyet Değişkenlerinin Çapraz Tablo Dağılımı

\begin{tabular}{|c|c|c|c|c|c|c|c|}
\hline \multirow{5}{*}{$\begin{array}{l}\text { Sosyal Medya } \\
\text { Platformunda Vakit } \\
\text { Geçirme Süreniz }\end{array}$} & & & Hiç & Nadiren & Bazen & Çoğunlukla & Sık sık \\
\hline & \multirow[t]{2}{*}{ Kadın } & Sayı & 1 & 10 & 37 & 59 & 22 \\
\hline & & $\%$ & 0.5 & 3.7 & 16.9 & 26.9 & 10.0 \\
\hline & \multirow[t]{2}{*}{ Erkek } & Sayı & 4 & 8 & 35 & 39 & 4 \\
\hline & & $\%$ & 1.8 & 4.6 & 16.0 & 17.8 & 1.8 \\
\hline \multirow{4}{*}{$\begin{array}{l}\text { Sosyal medyada } \\
\text { vergi ile ilgili kamu } \\
\text { spotu görme } \\
\text { sıklığınız? }\end{array}$} & Kadın & Sayı & 43 & 43 & 28 & 11 & 4 \\
\hline & & $\%$ & 19.6 & 19.6 & 12.8 & 5.0 & 1.8 \\
\hline & Erkek & Sayı & 32 & 37 & 17 & 4 & 0 \\
\hline & & $\%$ & 14.6 & 16.9 & 7.8 & 1.8 & 0.0 \\
\hline \multirow{4}{*}{$\begin{array}{l}\text { Dijital ortamdaki } \\
\text { sözlüklerde vergisel } \\
\text { konularda yorum } \\
\text { yazarım. }\end{array}$} & Kadın & Sayı & 94 & 20 & 12 & 2 & 1 \\
\hline & & $\%$ & 42.9 & 9.1 & 5.5 & 0.9 & 0.5 \\
\hline & Erkek & Sayı & 46 & 23 & 16 & 4 & 1 \\
\hline & & $\%$ & 21.0 & 10.5 & 7.3 & 1.8 & 0.5 \\
\hline \multirow{4}{*}{$\begin{array}{l}\text { Dijital ortamda vegi } \\
\text { ile ilgili yapılan } \\
\text { anketlere katılırım } \\
\text { sağlarım. }\end{array}$} & Kadın & Sayı & 62 & 29 & 26 & 10 & 2 \\
\hline & & $\%$ & 28.3 & 13.2 & 11.9 & 4.6 & 0.9 \\
\hline & Erkek & Sayı & 42 & 23 & 14 & 10 & 1 \\
\hline & & $\%$ & 19.2 & 10.5 & 6.4 & 4.6 & 0.5 \\
\hline \multirow{4}{*}{$\begin{array}{l}\text { Vergisel konularda } \\
\text { sanal } \\
\text { ansiklopedilere } \\
\text { (Wikipedia vs.) } \\
\text { başvururum }\end{array}$} & Kadın & Sayı & 54 & 26 & 21 & 21 & 7 \\
\hline & & $\%$ & 24.7 & 11.9 & 9.6 & 9.6 & 3.2 \\
\hline & Erkek & Sayı & 27 & 19 & 23 & 17 & 4 \\
\hline & & $\%$ & 12.3 & 8.7 & 10.5 & 7.8 & 1.8 \\
\hline \multirow{4}{*}{$\begin{array}{l}\text { Kişisel ve kurumsal } \\
\text { blog sayfalarında } \\
\text { vergi ile ilgili } \\
\text { konuları okurum. }\end{array}$} & Kadın & Sayı & 44 & 36 & 38 & 10 & 1 \\
\hline & & $\%$ & 20.1 & 16.4 & 17.4 & 4.6 & 0.5 \\
\hline & Erkek & Sayı & 28 & 22 & 25 & 10 & 5 \\
\hline & & $\%$ & 12.8 & 10.0 & 11.4 & 4.6 & 2.3 \\
\hline
\end{tabular}

Ankete katılan öğrencilerin sosyal medyada çoğunlukla vakit geçirdiklerini tablo 2'de görmekteyiz. Özellikle kız öğrencilerin daha fazla sosyal medyada vakit geçirdiklerini söyleyebiliriz. Öğrencilerin sosyal medyada vergi ile ilgili konularda paylaşımların az olduğunu ifade ettikleri ikinci soruda ise özellikle "hiç" ve "nadiren" şıklarını işaretleyenlerin katılımcıların oldukça önemli bir kısmı oldukları görülmektedir. 
"Dijital ortamdaki sözlüklerde vergisel konularda yorum yazarım" sorusuna ise kız öğrencilerin \%42.9'u ile erkek öğrencilerin \%21'i "hiç" yanıtını vermişler, bu yoruma "nadiren" ifadesine verilen cevapları da eklediğimizde kız öğrencilerin yarıdan fazlası ile erkek öğrencilerin \%31.5 kadarı vergi ile ilgili konularda sosyal medyada yorum yazmadıklarını beyan etmişlerdir. Diğer sorularda da dikkat çeken husus özellikle "hiç" ve "nadiren" şıklarını işaretleyenlerin katılımcıların önemli bir kısmını oluşturduğu görülmekte buradan da, öğrencilerin sosyal medyada vergi ile ilgili konularda ilgi düzeylerinin düşük olduğu gözlenmektedir.

Üniversite öğrencilerin sosyal medya kullanımları ile vergi algıları arasındaki ilişkiyi ortaya koymak adına toplam 10 soru yöneltilmiştir. Bu soruların ortalamaları alınarak "ortalama" değişkeni elde edilmiş ve bu değişkenin öğrencilerin bölümlerine göre bir farklılık gösterip göstermediğini tespit etmek için hipotezler aşağıdaki gibi oluşturulmuştur:

$\mathrm{H}_{0}$ : iiBF öğrencileri (bölüm bazında) arasında sosyal medya kullanımı ve vergi algısı arasında anlamlı bir farklılık vardır

$\mathrm{H}_{1}$ : IïBF öğrencileri (bölüm bazında) arasında sosyal medya kullanımı ve vergi algısı arasında anlamlı bir farklılık yoktur

Öğrenciler fakültedeki bölümleri dikkate alınarak; işletme, iktisat, maliye, uluslararası ticaret ve finans ile siyaset bilim ve kamu yönetimi olmak üzere toplam 5 grup mevcuttur.

Tablo 3. Sosyal Medya ve Vergi Algısı Hakkında Öğrencilerin Bölümleri Bazında Kruskall- Wallis Analizi

\begin{tabular}{|l|c|c|c|}
\hline & $\begin{array}{c}\text { test } \\
\text { istatistiği }\end{array}$ & $\mathbf{f}$ & anlamlılık \\
\hline $\begin{array}{l}\text { Sosyal Medya Kullanımı ve Vergi Algısı } \\
\text { (Toplam 10 değişken ortalaması alınarak elde edilmiş } \\
\text { "ortalama” değişkeni dikkate alınarak analiz yapılmıştır) }\end{array}$ & 5.040 & $\mathbf{. 0 0 0 *}$ \\
\hline
\end{tabular}

$*: p<0.05$

Kruskall- Wallis testi bulguları yorumlanırken anlamlılık hesaplamalarında kabul edilen sınır değer 0,05'tir. Anlamlılık düzeyi 0,05'ten büyük ise karşılaştırılan veriler arasında anlamlı bir fark olmadığını söylemek mümkündür. Ancak analiz sonucunda $p<0.05$ olduğundan, karşılaştırılan veriler arasında anlamlı bir fark olduğunu söylemek mümkündür. Buradan hareketle tek tek 10 sorunun ele alındığı test sonucunda sadece 0.05 düzeyinde anlamlı farklılığın tespit edildiği sorular aşağıdaki tablodaki gibidir. 
Gürler Hazman, G. \& Akbay, G. (2021). “Üniversite Öğrencilerinin Vergi Algıları Üzerine Sosyal Medyanın Etkileri", International Journal of Public Finance, 6(2), 312-331.

Tablo 4. Sosyal Medya ve Vergi Algısı Hakkında Anlamlı Farklılık Tespit Edilen Değişkenlere Ait Kruskall- Wallis Analizi

\begin{tabular}{|l|c|c|c|}
\hline Sosyal Medya ve Vergi Algısı Hakkında Sorular & $\begin{array}{c}\text { Test } \\
\text { istatistiği }\end{array}$ & df & Anlamlılık. \\
\hline $\begin{array}{l}\text { Sosyal medyada vergisel konulara yönelik bir etkinlik olursa } \\
\text { gönüllü katılırım. }\end{array}$ & 29.353 & 4 & $0.000^{*}$ \\
\hline $\begin{array}{l}\text { Dijital dünyada ve sosyal medya platformlarında vergi } \\
\text { reklamlarına daha çok yer verilmelidir. }\end{array}$ & 21.586 & 4 & $0.000^{*}$ \\
\hline $\begin{array}{l}\text { Dijital ortamda oluşturulan sözlüklerde (ekşi sözlük vs.) } \\
\text { vergisel yorumlar dikkatimi çeker. }\end{array}$ & 23.671 & 4 & $0.000^{*}$ \\
\hline $\begin{array}{l}\text { Vergi ile ilgili yaşanılan sorunlarda, sosyal medya } \\
\text { platformları fikir alış-verişi yapabilirim. }\end{array}$ & 16.119 & 4 & $0.003^{*}$ \\
\hline
\end{tabular}

$*: p<0.05$

Yapılan analizde sadece 4 soruda 0.05 düzeyinde anlamlı farklılık tespit edildiğinden sadece bu soruların yer aldığı test sonuçları tablo 3'te yer almaktadır. Bu sekiz değişken için $\mathrm{H}_{0}$ kabul $\mathrm{H}_{1}$ red edilmiştir. Bu durumda ikili karşılaştırma KruskallWallis testi ile mümkün olmadığı için bu sekiz ifadeyi post-hoc testlerinden birisi olan Tamhane Testi ${ }^{4}$ ile yapmak mümkündür

Tamhane Testinde 5 grup arasındaki ilişki incelenmiştir ve sonuçları aşağıdaki gibidir.

Tablo 5. Post-Hoc/ Tamhane Testi

\begin{tabular}{|c|c|c|c|c|}
\hline \multicolumn{3}{|c|}{ Değişkenler } & St. hata & p değeri \\
\hline \multirow{4}{*}{$\begin{array}{l}\text { Sosyal medyada vergisel } \\
\text { konulara yönelik bir etkinlik } \\
\text { olursa gönüllü katılırım. }\end{array}$} & İşletme & $\begin{array}{l}\text { Maliye } \\
\text { Iktisat } \\
\text { Kamu Yönetimi } \\
\text { UTF }\end{array}$ & $\begin{array}{l}0,210 \\
0.311 \\
0.269 \\
0.285\end{array}$ & $\begin{array}{c}0,00 * \\
0.54 \\
0.71 \\
0.45\end{array}$ \\
\hline & İktisat & $\begin{array}{l}\text { İşletme } \\
\text { Maliye } \\
\text { Kamu Yönetimi } \\
\text { UTF }\end{array}$ & $\begin{array}{l}0.311 \\
0.269 \\
0.317 \\
0.330\end{array}$ & $\begin{array}{l}0.54 \\
0.34 \\
1.00 \\
1.00\end{array}$ \\
\hline & Maliye & $\begin{array}{l}\text { İktisat } \\
\text { İşletme } \\
\text { Kamu Yönetimi } \\
\text { UTF }\end{array}$ & $\begin{array}{l}0,269 \\
0.210 \\
0.119 \\
0.238\end{array}$ & $\begin{array}{c}0,34 \\
0.00 * \\
0.02 * \\
0.16\end{array}$ \\
\hline & $\begin{array}{l}\text { Kamu } \\
\text { Yönetimi }\end{array}$ & $\begin{array}{l}\text { İktisat } \\
\text { İşletme } \\
\text { Maliye } \\
\text { UTF }\end{array}$ & $\begin{array}{l}0.317 \\
0.269 \\
0.219 \\
0.291\end{array}$ & $\begin{array}{c}1.00 \\
0.71 \\
0.02 * \\
1.00\end{array}$ \\
\hline
\end{tabular}

\footnotetext{
${ }^{4}$ Tamhane testi, grupların varyansları heterojen olduğunda kullanılan çoklu karşılaştırma testidir.
} 
Gürler Hazman, G. \& Akbay, G. (2021). "Üniversite Öğrencilerinin Vergi Algıları Üzerine Sosyal Medyanın Etkileri", International Journal of Public Finance, 6(2), 312-331.

\begin{tabular}{|c|c|c|c|c|}
\hline & UTF & $\begin{array}{l}\text { İktisat } \\
\text { İşletme } \\
\text { Maliye } \\
\text { Kamu Yönetimi }\end{array}$ & $\begin{array}{l}0.330 \\
0.285 \\
0.238 \\
0.291\end{array}$ & $\begin{array}{l}1.00 \\
0.45 \\
0.16 \\
1.00\end{array}$ \\
\hline \multirow{5}{*}{$\begin{array}{l}\text { Dijital dünyada ve sosyal medya } \\
\text { platformlarında vergi } \\
\text { reklamlarına daha çok yer } \\
\text { verilmelidir. }\end{array}$} & İşletme & $\begin{array}{l}\text { İtisat } \\
\text { Maliye } \\
\text { Kamu Yönetimi } \\
\text { UTF }\end{array}$ & $\begin{array}{l}0.307 \\
0.211 \\
0.303 \\
0.273\end{array}$ & $\begin{array}{c}0.98 \\
0.01^{*} \\
1.00 \\
1.00\end{array}$ \\
\hline & İktisat & $\begin{array}{l}\text { İşletme } \\
\text { Maliye } \\
\text { Kamu Yönetimi } \\
\text { UTF }\end{array}$ & $\begin{array}{l}0.307 \\
0.272 \\
0.348 \\
0.322\end{array}$ & $\begin{array}{l}0.98 \\
0.75 \\
1.00 \\
0.91\end{array}$ \\
\hline & Maliye & $\begin{array}{l}\text { İktisat } \\
\text { İşletme } \\
\text { Kamu Yönetimi } \\
\text { UTF }\end{array}$ & $\begin{array}{l}0.272 \\
0.211 \\
0.267 \\
0.233\end{array}$ & $\begin{array}{c}0.74 \\
0.01^{*} \\
0.21 \\
0.01^{*}\end{array}$ \\
\hline & $\begin{array}{l}\text { Kamu } \\
\text { Yönetimi }\end{array}$ & $\begin{array}{l}\text { İktisat } \\
\text { İşletme } \\
\text { Maliye } \\
\text { UTF }\end{array}$ & $\begin{array}{l}0.348 \\
0.303 \\
0.267 \\
0.319\end{array}$ & $\begin{array}{l}1.00 \\
1.00 \\
0.21 \\
1.00\end{array}$ \\
\hline & UTF & $\begin{array}{l}\text { İktisat } \\
\text { İşletme } \\
\text { Maliye } \\
\text { Kamu Yönetimi }\end{array}$ & $\begin{array}{l}0.322 \\
0.273 \\
0.233 \\
0.319\end{array}$ & $\begin{array}{c}0.91 \\
1.00 \\
0.01^{*} \\
1.00\end{array}$ \\
\hline \multirow{5}{*}{$\begin{array}{l}\text { Dijital ortamda oluşturulan } \\
\text { sözlüklerde (ekşi sözlük vs.) } \\
\text { vergisel yorumlar dikkatimi } \\
\text { çeker. }\end{array}$} & İşletme & $\begin{array}{l}\text { İktisat } \\
\text { Maliye } \\
\text { Kamu Yönetimi } \\
\text { UTF }\end{array}$ & $\begin{array}{l}0.344 \\
0.224 \\
0.332 \\
0.288\end{array}$ & $\begin{array}{c}0.96 \\
0.0 *^{*} \\
1.00 \\
0.77\end{array}$ \\
\hline & İktisat & $\begin{array}{l}\text { İşletme } \\
\text { Maliye } \\
\text { Kamu Yönetimi } \\
\text { UTF }\end{array}$ & $\begin{array}{l}0.344 \\
0.303 \\
0.390 \\
0.353\end{array}$ & $\begin{array}{l}0.96 \\
0.37 \\
1.00 \\
1.00\end{array}$ \\
\hline & Maliye & $\begin{array}{l}\text { İktisat } \\
\text { İşletme } \\
\text { Kamu Yönetimi } \\
\text { UTF }\end{array}$ & $\begin{array}{l}0.303 \\
0.224 \\
0.289 \\
0.238\end{array}$ & $\begin{array}{c}0.37 \\
0.0 *^{*} \\
0.05 \\
0.19\end{array}$ \\
\hline & $\begin{array}{l}\text { Kamu } \\
\text { Yönetimi }\end{array}$ & $\begin{array}{l}\text { İktisat } \\
\text { İşletme } \\
\text { Maliye } \\
\text { UTF }\end{array}$ & $\begin{array}{l}0.390 \\
0.332 \\
0.289 \\
0.342\end{array}$ & $\begin{array}{l}0.19 \\
1.00 \\
0.05 \\
0.99\end{array}$ \\
\hline & UTF & $\begin{array}{l}\text { İktisat } \\
\text { İşletme } \\
\text { Maliye } \\
\text { Kamu Yönetimi }\end{array}$ & $\begin{array}{l}0.353 \\
0.288 \\
0.238 \\
0.342\end{array}$ & $\begin{array}{l}1.00 \\
0.77 \\
0.19 \\
0.99\end{array}$ \\
\hline
\end{tabular}


Gürler Hazman, G. \& Akbay, G. (2021). “Üniversite Öğrencilerinin Vergi Algıları Üzerine Sosyal Medyanın Etkileri", International Journal of Public Finance, 6(2), 312-331.

Vergi ile ilgili yaşanılan sorunlarda, sosyal medya platformları fikir alış-verişi yapabilirim.

\begin{tabular}{|c|c|c|c|}
\hline İşletme & $\begin{array}{l}\text { İktisat } \\
\text { Maliye } \\
\text { Kamu Yönetimi } \\
\text { UTF }\end{array}$ & $\begin{array}{l}0.310 \\
0.237 \\
0.310 \\
0.297\end{array}$ & $\begin{array}{c}0.99 \\
0.01 * \\
0.61 \\
0.77\end{array}$ \\
\hline İktisat & $\begin{array}{l}\text { İşletme } \\
\text { Maliye } \\
\text { Kamu Yönetimi } \\
\text { UTF }\end{array}$ & $\begin{array}{l}0.310 \\
0.241 \\
0.314 \\
0.300\end{array}$ & $\begin{array}{l}0.99 \\
0.22 \\
0.98 \\
0.98\end{array}$ \\
\hline Maliye & $\begin{array}{l}\text { İktisat } \\
\text { İşletme } \\
\text { Kamu Yönetimi } \\
\text { UTF }\end{array}$ & $\begin{array}{l}0.241 \\
0.237 \\
0.241 \\
0.223\end{array}$ & $\begin{array}{c}0.22 \\
0.01 * \\
0.95 \\
0.69\end{array}$ \\
\hline $\begin{array}{l}\text { Kamu } \\
\text { Yönetimi }\end{array}$ & $\begin{array}{l}\text { İktisat } \\
\text { İşletme } \\
\text { Maliye } \\
\text { UTF }\end{array}$ & $\begin{array}{l}0.314 \\
0.310 \\
0.241 \\
0.300\end{array}$ & $\begin{array}{l}0.98 \\
0.61 \\
0.55 \\
1.00\end{array}$ \\
\hline UTF & $\begin{array}{l}\text { İktisat } \\
\text { İşletme } \\
\text { Maliye } \\
\text { Kamu Yönetimi }\end{array}$ & $\begin{array}{l}0.300 \\
0.297 \\
0.223 \\
0.300\end{array}$ & $\begin{array}{l}0.99 \\
0.77 \\
0.69 \\
1.00\end{array}$ \\
\hline
\end{tabular}

$*: p<0.05$

Toplam 4 soruda farklılık tespit edilmiş olup bu farklılıkların sınanmasının amacı, farklı bölümü öğrencilerinin vergi algısı ve sosyal medya ilişkisi hakkındaki algılarının bölümlere göre farklılık gösterip göstermediğinin tespit edilmesidir. Fakültede yer alan 5 bölüm içinde en fazla vergi dersini Maliye bölümü öğrencileri görmektedir. Dolayısıyla lisans eğitimi boyunca Maliye bölümü öğrencilerinin diğer bölüm öğrencileri ile araştırma konusu hakkında sahip oldukları farklılıkları görmek hedeflenmiştir. Lisans eğitim boyunca aldıkları vergi vb. dersler daha fazla olduğundan Maliye bölümü öğrencileri ile diğer bölümler arasında farklıık çıkması beklenmiştir. Test sonucunda beklentiye uyumlu sonuçlar ile karşılaşılmıştır. Yukarıdaki tablodan da görüldüğü üzere birinci ifadede (Sosyal medyada vergisel konulara yönelik bir etkinlik olursa gönüllü katılırım.); İşletme ile Maliye bölümü ve Kamu Yönetimi ile Maliye bölümü arasında Tamhane değeri $p<0,05$ çıkmıştır. Yine ikinci ifadede (Dijital dünyada ve sosyal medya platformlarında vergi reklamlarına daha çok yer verilmelidir.); İ̧̧letme ile Maliye bölümü ve UTF ile Maliye bölümü arasında Tamhane değeri $p<0,05$ çıkmıştır. Son olarak üçüncü (Dijital ortamda oluşturulan sözlüklerde (ekşi sözlük vs.) vergisel yorumlar dikkatimi çeker) ve dördüncü ifadede (Vergi ile ilgili yaşanılan sorunlarda, sosyal medya platformları fikir alış-verişi yapabilirim.); İşletme ile Maliye bölümü arasında Tamhane değeri $p<0,05$ çıkmıştır.

Ankete katılan öğrencilerin sosyal medya kullanımlarında vergi ile ilgili konularda neler düşündüklerini ölçmek için iki seçenekli 5 adet soru yöneltilmiştir. Bu sorulara verilen cevaplar aşağıdaki gibidir. 
Gürler Hazman, G. \& Akbay, G. (2021). "Üniversite Öğrencilerinin Vergi Algıları Üzerine Sosyal Medyanın Etkileri", International Journal of Public Finance, 6(2), 312-331.

Tablo 6: Sosyal Medya Kullanımında "Vergi" ile Iilgili Konulara ilgi

\begin{tabular}{|l|c|c|c|}
\hline & Evet (\%) & Hayır (\%) & Toplam (\%) \\
\hline $\begin{array}{l}\text { Gelir İdaresi Başkanlığı sosyal medya platformlarından } \\
\text { haberdar mısınız? }\end{array}$ & 38.4 & 61.6 & 100 \\
\hline $\begin{array}{l}\text { Gelir Idaresi Başkanlığı sosyal medya platformlarını takip } \\
\text { ediyor musunuz? }\end{array}$ & 20.5 & 79.5 & 100 \\
\hline $\begin{array}{l}\text { Sosyal medya platformlarında veya dijital dünyada } \\
\text { üniversitenizin vergisel konularda yayınlar yapmalı mı? }\end{array}$ & 79.0 & 21.0 & 100 \\
\hline $\begin{array}{l}\text { Sosyal medya platformlarında vergi ile ilgili gruplara } \\
\text { (facebook grupları vs.) üyeyimdir. }\end{array}$ & 8.2 & 91.8 & 100 \\
\hline $\begin{array}{l}\text { Vergi işlemlerinin dijital ortamda yapılmasını güvenli } \\
\text { buluyorum. }\end{array}$ & 66.2 & 33.8 & 100 \\
\hline
\end{tabular}

Ankete katılan öğrencilerin çoğunluğunun Gelir İdaresi Başkanlığı'nın sosyal medya platformlarını takip etmediği ve yine sosyal medyada vergi ile ilgili gruplara üyelik vb. olmadığı yani ilgi düzeylerinin düşük olduğu söylenebilir. Dijital ortamda vergisel işlemlerin yapılmasının güvenli olduğunu ancak kendi sosyal medya platformlarında vergi ile ilgili konulara pek fazla ilgi duymadıkları söylenebilir.

\section{Sonuç}

Vergi uyumunu sağlama ve gönüllü uyumu etkileyen faktörler konusu, verginin kendisi kadar eski bir konudur çünkü verginin varoluşu ile birlikte mükellefler için yaşanagelmiş bir histir. Mükellefler vergi ödeme ile birlikte ya huzursuzluk ya da huzur hissedebilirler, söz konusu his eğer huzursuzluk ise; vergi algısı zayıflayarak vergi sisteminin etkilerini anlamak, verginin amaçlarını bilmek ve önemsemek açısından isteksiz ve özensiz davranırlar. Mükellefin vergi ile ilgili ödev ve sorunluluklarını yerine getirmedeki isteklilik düzeyi zayıfladıkça vergi kayıp ve kaçakları da artacak ve bu durum sürekli gerçekleşen bir sorun olarak devam edecektir.

Vergi uyumsuzluğu yani vergi mükelleflerinin vergi mevzuatına göre yükümlülüklerini tam ve eksiksiz veya zamanında yerine getirmemeleri, vergi gelirlerini potansiyel vergi gelirinin gerisine taşıyacak ve istenilen düzeyde vergi geliri tahsilatı sağlanamayacaktır. Vergi uyumunu etkileyen pek çok faktör hakkında literatürde çeşitli araştırmalar yapılmış olup, bunlar arasında internet kullanımının ve teknolojinin gelişmesiyle birlikte sosyal medya kullanımının etkisini araştırmak, bu çalışmanın amacını oluşturmaktadır.

Bu amaç için hedef grup olarak üniversite öğrencileri tercih edilmiş ve vergi algıları ile sosyal medya kullanım alışkanlıkları arasında bir ilişki olup olmadığını ortaya koymak hedeflenmiştir. Böylece öğrencilerin internet kullanımı ile birlikte sosyal medya kullanımlarının vergi algısı ile olan bağlantısını tespit ederek, vergi algısını yükseltmede kamu spotları aracılığı ile halkın vergi algısını daha yüksek tutmak 
yönünde öneriler getirilebilecektir. Anket formu geliştirilerek Afyon Kocatepe Üniversitesi iiBF bünyesinde aktif kayıtlı öğrencilere Mayıs 2021 ile Haziran 2021 aralığında 219 öğrenci ile uygulama yapılmıştır.

Analiz sonuçlarına göre; iïBF öğrencileri (bölüm bazında) arasında sosyal medya ve vergi algısı hakkında anlamlı bir farklılık olup olmadığı sınanmak istenmiş ve fakülte içinde farklı bölümü öğrencilerinin vergi algısı ve sosyal medya ilişkisi hakkındaki algılarının bölümlere göre farklılık gösterip göstermediğinin tespit edilmesi amaçlanmıştır.

Anket yapılan fakültede yer alan 5 bölüm içinde en fazla vergi dersi Maliye bölümü öğrencilerinin müfredatlarında mevcuttur. Dolayısıyla lisans eğitimi boyunca Maliye bölümü öğrencileri vergi ile ilgili dersleri diğer bölüm öğrencilerine kıyasla daha fazla almaktadır. Buradan hareketle araştırma konusu hakkında sahip oldukları algı farklııklarını görmek hedeflenmiştir. Lisans eğitim boyunca aldıkları vergi vb. dersler daha fazla olduğundan Maliye bölümü öğrencileri ile diğer bölümler arasında farklılık çıkması beklenmiştir.

Test sonucunda beklentiye uyumlu sonuçlar ile karşılaşılmıştır. Özellikle bazı ifadelerde örneğin; "Sosyal medyada vergisel konulara yönelik bir etkinlik olursa gönüllü katılırım" ile; İşletme ile Maliye bölümü ve Kamu Yönetimi ile Maliye bölümü arasında Tamhane test değeri $p<0,05$ çıkmıştır. Bu durumda bölümler arasında yani Maliye bölümü ile diğer bölümler arasındaki farklılık dikkatlerden kaçmamaktadır. Yine ikinci ifadede "Dijital dünyada ve sosyal medya platformlarında vergi reklamlarına daha çok yer verilmelidir" ifadesinde de; İşletme ile Maliye bölümü ve UTF ile Maliye bölümü arasında Tamhane test değeri $p<0,05$ çıkmıştır. Hatta üçüncü olarak "Dijital ortamda oluşturulan sözlüklerde (ekşi sözlük vs.) vergisel yorumlar dikkatimi çeker" ve dördüncü olarak "Vergi ile ilgili yaşanılan sorunlarda, sosyal medya platformları fikir alış-verişi yapabilirim" ifadelerinde İşletme ile Maliye bölümü arasında Tamhane test değeri $p<0,05$ çıkmıştır.

Çalışmanın genel sonucu olarak ankete katılan öğrencilerin çoğunluğunun vergi ile ilgili konularda sosyal medya üzerinde ilgi düzeylerinin düşük olduğu söylenebilir. Çünkü yapılan ankette elde edilen bulgular öğrencilerin, Gelir Idaresi Başkanlığı'nın sosyal medya platformlarını takip etmediği ve yine sosyal medyada vergi ile ilgili gruplara üyelik vb. konusunda istekliliklerinin düşük olduğu, yani ilgi düzeylerinin düşük olduğu söylenebilir. Tüm bunların yanında dijital ortamda vergisel işlemlerin yapılmasının güvenli olduğunu düşünmekte yani iş ev işlemlerin internet sayesinde hızlanacağını bilmekte ancak kendi sosyal medya platformlarında vergi ile ilgili konulara pek fazla ilgi duymadıkları görülmektedir. Buradan hareketle özellikle vergi otoritesinin toplumdaki vergi algısını arttırmak adına, sosyal medyada vergi ile ilgili olumlu paylaşımların yapılmasını teşvik etmesi, gerek kamu spotları gerekse on-line bilgi paylaşım platformlarıyla verginin öneminin daha fazla vurgulanması öneri olarak getirilebilir. 


\section{Kaynakça}

Akın, M. Ş. (2019), “Davranışsal Iktisatta Uygulamalı Örneklerle Pasif Metotlar: Başlangıç Ayarı ve Bağlam Etkisi", Ekonomi Bilimleri Dergisi, 11(2), 149-167.

Akman, T. K. (2011). Türk Vergi Hukuku, İlya İzmir Yayınevi: İzmir.

Aksoy, Şerafettin (1998). Kamu Maliyesi, Filiz Kitabevi: İstanbul.

Aktan, C. C. \& Çoban, H. (2007). "Kamu Maliyesine Güven ve Ekonomik Anayasa", Çimento Işveren Dergisi, 21(6) 1-7.

Aktan, C. C. \& Çoban, H. (2006), "Vergileme Ekonomisi ve Vergileme Psikolojisi Perspektifinden Vergiye Karşı Tutum ve Davranışları Belirleyen Faktörler", Vergileme Ekonomisi ve Vergileme Psikolojisi, Seçkin Yayınevi, Ankara.

Allingham, M. G. \& Sandmo, A. (1972). "Income Tax Evasion: A Theoretical Analysis", Journal of Public Economic, 1(3-4), 323-338.

Altunışık, R., Coşkun, R., Bayraktaroğlu, S. \& Yıldırım E. (2010). Sosyal Bilimlerde Araştırma Yöntemleri, Sakarya Yayıncılık, Sakarya.

Andreoni, J., Erard, B. \& Feınsteın, J. (1998). "Tax Compliance", Journal of Economic Literature, 36(2), 818-860.

Aydın, M. (2013). Türkiye'de Vergileme ve Işsizlik, IJOPEC Yayınları: İstanbul.

Çanakkale, O. F. (2016). "Teknolojik Illerlemenin Vergiye Gönüllü Uyuma Etkisi”, Vergi Sorunları Dergisi, 329, 57-61.

Doğan, U. (2015). “Vergi Teknolojileri”, Vergi Sorunları Dergisi, 322, 9-40.

Edizdoğan, N.(1998). Kamu Maliyesi 2, 4. Baskı, Ekin Kitabevi: Bursa.

Edizdoğan, N., Çetinkaya, Ö. \& Gümüş, E. (2018). Kamu Maliyesi, Ekin Yayınevi: Bursa.

Gelir İdaresi Başkanlığı Faaliyet Raporu, 2019.

Gelir İdaresi Başkanlığı Faaliyet Raporu, 2020.

Henderson, A. \& Bowley, R. (2010). "Authentic Dialogue? The Role of Friendship in a Social Media Recruitment Campaign", Journal of Communication Management, 14(3), 237-257.

Ince, M. \& Koçak M. C. (2017). "Üniversite Öğrencilerinin Sosyal Medya Kullanım Alışkanlıkları: Necmettin Erbakan Üniversitesi Örneği”, Karabük Üniversitesi Sosyal Bilimler Enstitüsü Dergisi, 7(2), 736-749.

Kahneman, D. \& Tversky, A. (1979). "Prospect Theory: An Analysis of Decision Under Risk", Econometrica, 47/2, 263-292. 
Kitapcı, i. (2015). Vergi Etiği-Vergi Psikolojisi (Verginin Sosyo-Psikolojik Teorisi), 3. Baskı, Seçkin Yayıncılık: Ankara.

Lubian, D. \& Luca Z. (2011). "Happiness and Tax Morale: an Emprical Analysis", Working Paper Series Department of Economics University of Verona, WP Number: 4, ISSN: 2036-2919 (paper), 2036-4679, 1-39.

Norris, P. (1999). "Conclusion: The Growth of Critical Citizens and its Consequences" (Ed) P.Norris, Critical Citizens, Global Support for Democratic Governance, Oxford University Press USA-OSO.

Obee, J. (2012). The Ultimate Teen Guide, Toronto: The Scarecrow Press.

Orhaner, E. (2007). Kamu Maliyesi, Siyasal Kitabevi: Ankara.

Özdamar, K. (2002). Modern Bilimsel Araştırma Yöntemleri, Kaan Kitabevi, Eskişehir.

Özperhiz, N.(2005). "Vergi Uyumu ve Ülkemizde Vergi Uyumunun Artırılmasına Yönelik Öneriler", Vergi Dünyası, 283, 90-94.

Roth, J. A., Scholz, J. T. \& Witte, A. D. (Eds) (1989). Taxpayer Compliance, Vol.1: An Agenda for Research, Philadelphia: University of Pennsylvania Press.

Sirkeci, O. \& Elbeyoğlu, K. (2019). "Kamu Maliyesi ve Vergi Etiğinde Makyavelizm", Vergi Sorunları Dergisi, 373, 9-23.

Thaler, R. H. \& Sunstein, C. R. (2019), Nudge: Improving Decisions About Health, Wealth, and Happiness, London, Book Review, UK: Penguin, ISBN: 978-0-14104001-1, 1-3.

Torgler, B. (2007). Tax Compliance and Tax Morale, A Theoretical and Emprical Analysis, Edward Elgar, UK. 